\title{
Duchenne muscular dystrophy Quality of life among 95 patients evaluated using the Life Satisfaction Index for Adolescents
}

\author{
Valdecir A. Simon', Maria Bernardete Dutra Resende1, \\ Margarete A.V.P. Simon'2, Edmar Zanoteli ${ }^{1,3}$, Umbertina Conti Reed $^{1}$
}

\begin{abstract}
The purpose of this study was to evaluate the quality of life $(\mathrm{Q} O L)$ of patients with Duchenne muscular dystrophy (DMD) in different stages of the disease, by means of the Life Satisfaction Index for Adolescents (LSI-A). The practicality of this scale was also verified. The LSI-A was applied four times to 95 patients with DMD who were undergoing steroid therapy, at three-month intervals. The patients were divided into four groups according to age. The results from the four applications and the inter and intra-examiner concordance were treated statistically. Comparing the different age groups, patients with DMD did not lose QoL, even with disease progression. We concluded that, in spite of the progressive course of the disease, the $\mathrm{QoL}$ in patients with DMD does not get worse. The use of a scale that embraces a great diversity of circumstances in patients' lives, without considering clinical aspects excessively, is a good alternative for assessing the QoL of these patients. Key words: quality of life, Duchenne muscular dystrophy, steroid therapy, questionnaire, Life Satisfaction Index for Adolescents.
\end{abstract}

Distrofia muscular de Duchenne: avaliação da qualidade de vida em 95 pacientes através do Life Satisfaction Index for Adolescents

\section{RESUMO}

O objetivo deste estudo foi de quantificar a qualidade de vida (OV) em crianças com distrofia muscular de Duchenne (DMD) em diferentes idades através do uso do questionário Life Satisfaction Index for Adolescents (LSI-A). Foi também avaliada a praticidade do questionário. O LSI-A foi aplicado a 95 pacientes com distrofia muscular de Duchenne em corticoterapia, em diferentes idades, e por quatro vezes com intervalos de três meses. Os resultados concernentes às quatro avaliações e a concordância inter e intra-observador foram tratados estatisticamente. Comparando diferentes faixas etárias, mesmo ao longo da progressão da doença, não notamos perda da QV. Concluímos que por não valorizar excessivamente os aspectos clínicos e abranger uma diversidade de circunstâncias cotidianas, O LSI-A é útil na avaliação da QV das crianças com DMD, sendo também de fácil aplicação.

Palavras-chave: qualidade de vida, distrofia muscular de Duchenne, corticoterapia, questionário, Life Satisfaction Index for Adolescents.

\author{
Correspondence \\ Valdecir A. Simon \\ Av. Dr. Eneas de Carvalho \\ Aguiar, 255 / sala 5083 \\ 05403-000 São Paulo SP - Brasil \\ E-mail: valdecirsimon@usp.br
}

Received 18 January 2010

Received in final form 13 August 2010

Accepted 20 August 2010
Duchenne muscular dystrophy (DMD) is a degenerative disease with sex-linked recessive inheritance caused by mutations in the dystrophin gene in $\mathrm{Xp} 21^{1,2}$. The disease shows high prevalence and incidence and affects one in 3,600 to 6,000 liveborn males $^{3,4}$. DMD has a progressive and irre- versible clinical course that initially is predominantly in the proximal limb-girdle muscles ${ }^{5}$. The symmetrical and progressive decline in muscle strength and motor skills over the course of time was well established by Scott et al. ${ }^{6}$, and the annual decline in muscle strength is around $2 \%{ }^{7}$.

${ }^{1}$ Department of Neurology, School of Medicine, University of São Paulo, São Paulo SP, Brazil; ${ }^{2}$ University São Judas Tadeu, São Paulo SP, Brazil; ${ }^{3}$ Assistance Association for Handicapped Children (AACD), São Paulo SP, Brazil. 
The main causes of death are cardiac muscle impairment, occurring in $70 \%$ of the patients, and restrictive respiratory failure ${ }^{8,9}$.

Among patients with DMD, steroid therapy delays the loss of muscle strength and respiratory capacity ${ }^{10-12}$. Steroid therapy improves muscle strength within two to four months after beginning the treatment, and it helps to maintain independent walking for at least two more years $^{13}$. In addition, steroid therapy has a positive and significant impact on quality of life (QoL) and on the cost/ benefit relationship of medical care ${ }^{14,15}$. In addition to steroid therapy, non-invasive mechanical ventilation methods are important palliative approaches involving QoL $^{16}$. In short, respiratory and heart support in association with steroid therapy currently enables survival beyond 30 years of age. with the patient maintaining good QoL ${ }^{17}$.

QoL assessments relate more to subjective issues, such as negative and positive aspects of perceptions and individual expectations of life, than to objective issues, i.e. environmental and social variables. Good assessment methods need to be multidimensional and to reflect cultural influences ${ }^{18}$. QoL questionnaires ${ }^{19}$ should not only detect changes in QoL over the course of evolution of the disease, but also help to predict future disability and the prognosis ${ }^{20}$.

The Life Satisfaction Index for Adolescents (LSI-A) questionnaire was developed by Reid and Renwick ${ }^{21}$ in 1994 and was validated in a study on 15 adolescents with DMD. It evaluates five domains relating to satisfaction with life: general wellbeing, interpersonal relationships, personal development, personal satisfaction and leisure and recreation. It includes a total of 45 items and can be either self-administered or applied by family members or multidisciplinary staff. This questionnaire has minimal interference with motor function and clinical issues, and thus it seems to be a very effective means for DMD patients to assess their QoL. Given the scarcity of studies on QoL relating to DMD, we applied the LSI-A to a large group of patients with DMD, of different ages, in order to find out whether the progression of the disease affects patients' QoL and, in addition, to investigate the practicality and effectiveness of this questionnaire for DMD patients.

\section{METHOD}

We evaluated 95 patients with DMD, aged 5 to 17 years, who had been undergoing steroid therapy with prednisolone (intermittent use of $0.75 \mathrm{mg} / \mathrm{kg} /$ day, orally, in alternating periods of 10 days on/off) or deflazacort (continuous use of $0.9 \mathrm{mg} / \mathrm{kg} /$ day, orally) and were being followed up at the Outpatient Clinic for Neuromuscular Diseases at our Institution. The diagnosis of DMD was made by molecular testing or immunohistochemistry/ Western blotting of dystrophin in muscle biopsy samples.
After obtaining prior authorization from the authors ${ }^{21}$, the Life Satisfaction Index for Adolescents questionnaire was applied to all patients between May 2007 and October 2008. In order to ensure greater accuracy and precision for the data obtained from the questionnaire, it was applied on four different occasions with three-month intervals between the applications. The patients were divided into four groups according to age: Group $A(n=11)$, from five to seven years of age; group $B(n=40)$, from eight to 10 years; group $C(n=28)$, from 11 to 13 years; and group $D(n=16)$, from 13 to 17 years of age. The questionnaire was adapted verbally so that it would be understood by children under 12 years of age. The only interventions made were in relation to the definitions of some words, when necessary. Because of the need to understand the questionnaire, patients with mental retardation were excluded. The patients' parents signed a consent form in accordance with the approval granted by the Ethics Committee of our Institution. The statistical methodology was based on Rosner ${ }^{22}$. The agreement between pairs of examiners (inter-observer reliability) and the agreement between the observations made by the same examiner on different occasions (intra-observer reliability and test-retest) were evaluated using the Bland-Altman graphical method. Intra and inter-observer measurements were made on $31 \%$ of patients, and their values were found to be concentrated between -1 and +1 . The Kruskal-Wallis test was used for comparisons between the groups at each application and, when the comparison was significant, the Dunn test was applied. The Friedman test allowed us to compare different moments of the evaluation in each group. To compare the average of the four evaluations between the four groups in all five domains, we used one-way ANOVA. For all statistical measurements, the significance level of $\mathrm{p}<0.05$ was used.

\section{RESULTS}

Among the 95 patients, 39 were wheelchair users, and two of the latter had motorized chairs. Concerning education levels, eight patients had not attended any school, three had reached high school level (two had professional occupations) and 82 had completed elementary school. The patients were always accompanied by their caregivers when they came to the hospital for appointments. Ninety-two patients were accompanied by their parents; two were under the care of grandparents and one was under the tutelage of his stepfather.

In the General Wellbeing domain, the mean score showed a statistically significant increase $(p<0.05)$ only in group B (8-10 years of age), therefore signifying an increase in QoL over the nine months of follow-up. The domains of Personal Development, Personal Satisfaction, Leisure and Recreation and Interpersonal Relationship 
Table. Representation of the scores obtained in the LSI-A domains.

\begin{tabular}{cccccc}
\hline Group N & $\begin{array}{c}\text { General } \\
\text { Wellbeing [A] }\end{array}$ & $\begin{array}{c}\text { Interpersonal } \\
\text { Relationship [B] }\end{array}$ & $\begin{array}{c}\text { Personal } \\
\text { Development [C] }\end{array}$ & $\begin{array}{c}\text { Personal } \\
\text { Satisfaction [D] }\end{array}$ & $\begin{array}{c}\text { Leisure and } \\
\text { Recreation [E] }\end{array}$ \\
\hline A -11 & $28.5 \pm 3.665$ & $33.625 \pm 3.462$ & $35.125 \pm 2.992$ & $33.125 \pm 1.83$ & $34.375 \pm 2.857$ \\
B -40 & $28.25 \pm 3.267$ & $34.212 \pm 2.927$ & $35.265 \pm 2.712$ & $33 \pm 2.007$ & $33.875 \pm 3.375$ \\
C -28 & $28.06 \pm 2.722$ & $34.25 \pm 3.562$ & $35.25 \pm 3.877$ & $32.937 \pm 3.235$ & $33.312 \pm 3.48$ \\
D -16 & $29.625 \pm 3.272$ & $35.9 \pm 3.595$ & $36.06 \pm 4.53$ & $33.5 \pm 2.57$ & $34.625 \pm 3.037$ \\
\hline
\end{tabular}

[A] General Wellbeing, [B] Interpersonal Relationship, [C] Personal Development, [D] Personal Satisfaction and [E] Leisure and Recreation, over the followup period in the four groups of patients with DMD. The comparisons between the four groups did not show any significant differences (one-way ANOVA, $\mathrm{p}>0.05)$. N: number of patients.

showed statistically significant increases over the course of the four evaluations in all groups $(\mathrm{p}<0.05)$. These results indicated that over this period of evaluation, the patients were able to cope with the disease without demonstrating anxiety, were satisfied with their lives, had active participation in cultural life and maintained good affective and social contact with friends and relatives.

Comparing the averages of the four evaluations between the four groups in all the five domains, there was no statistically significant difference (one-way ANOVA; $\mathrm{p}>0.05$ ) (Table). We considered this result to be satisfactory, because it indicated that there was no loss of QoL among the older children who were more affected because of the progressive course of the disease.

\section{DISCUSSION}

In this study, we observed that there was no significant difference in QoL comparisons between different age groups of patients with DMD, despite the progressive course of the disease. In facing up to this disease, determination of the subjective aspects of QoL is essential for the clinical evaluation and complements it. Specific instruments that can accurately depict patients' interpretations of the disease are required. Although several QoL questionnaires can be applied to evaluate patients with serious chronic diseases, there are few studies relating to DMD. However, it is clear that systematic application of QoL questionnaires to patients with DMD who are highly disabled and aware of their prognosis, is extremely valuable for adequate multidisciplinary therapeutic planning and for better support for patients and their families.

It is important to evaluate QoL not only through caregivers' opinions but also through patients' perspectives, because the parents may have a negative perception about their child. To analyze this issue, Gonçalves et al. ${ }^{23}$ applied the questionnaire Autoquestionnaire Qualité de Vie Enfant Imagé (AUQUEI). This has already been validated in Brazil $^{24}$ and is composed of 26 questions that assess family relationships, social activities, health and body functions. Among 18 DMD patients and their 18 caregivers, they did not observe any statistical difference between the scores obtained through the perceptions of children and caregivers. The mothers and their children shared the same opinions, and the children's QoL was considered satisfactory.

Melo et al. ${ }^{25}$ applied AUQUEI to 14 children with DMD and found that they had good QoL. They also noted that there was agreement between the children and their caregivers. The most representative domains that they assessed were function, family and leisure. Interestingly, the children gave more importance to obtaining better mobility using their wheelchairs than using supported gait. The practicality of the AUQUEI questionnaire is relevant but, because evaluating QoL is a complex matter, we believe that this questionnaire is deficient with regard to the diversity of circumstances surrounding life and human QoL.

Another questionnaire that can be applied to these patients is the Medical Outcomes Study 36-item ShortForm (SF-36) $)^{26,27}$. This is divided into eight domains and covers physical and functional characteristics. However, the SF-36 clearly correlates the progressive decline due to DMD with a decline in QoL. Activities of daily living are not the only parameters for assessing QoL, and this is often unrelated to the physical disability ${ }^{28}$. Given that patients' survival has now increased considerably, in spite of the unavoidable progression of the motor and respiratory dysfunction, we believe that the SF-36 is inappropriate for assessing the QoL of DMD patients because it emphasizes the clinical aspects of the disease.

The LSI-A questionnaire seems to be adequate for DMD patients, since its five domains cover a great diversity of daily circumstances. The questions correlate to a lesser degree with the clinical findings, and therefore enable a more accurate quantification of patients' QoL. Although this questionnaire was recommended for patients over 12 years of age, we found in our study that the it was also applicable to younger children, although requiring cultural adjustment.

In conclusion, our QoL assessment using LSI-A among 95 patients with DMD showed that there was no lose of 
QoL, even among the older children who were more affected by the diseases, probably because this scale covers a wide variety of daily circumstances and does not give excessive value to the clinical aspects. According to Bray et al. ${ }^{29}$, QoL is independent of clinical aspects. The questionnaire accurately expressed QoL and met the requirements for QoL assessment among children with DMD.

\section{REFERENCES}

1. Koenig M, Monaco AP, Kunkel LM. The complete sequence of dystrophin predicts a rod-shaped cytoskeletal protein. Cell 1988;53:219-228.

2. Hoffman EP, Monaco AP, Feener CC, Kunkel LM. Conservation of the Duchenne muscular dystrophy gene in mice and humans. Science 1987; 238:347-350.

3. Hernández LBL, Cárdenas NAV, Padrón EL. Distrofia muscular de Duchenne: actualidad y perspectivas de tratamiento. Rev Neurol 2009;49:363-369.

4. Bushby K, Finkel R, Birnkrant DJ, et al. Diagnosis and management of Duchenne muscular dystrophy, part 1: diagnosis, and pharmacological and psychosocial management. Lancet Neurol 2010;9:77-93.

5. Caromano FA. Características do portador de distrofia muscular de Duchenne: revisão. Arq Cienc Saude Unipar 1999;3:211-218.

6. Scott OM, Goddard C, Dubowitz V. Quantification of muscle function in children: a prospective study in Duchenne muscular dystrophy. Muscle Nerve 1982;5:291-301.

7. Steffensen BF, Lyager S, Werge B, et al. Physical capacity in non-ambulatory people with Duchenne muscular dystrophy or spinal muscular atrophy: a longitudinal study. Dev Med Child Neurol 2002;44:623-632.

8. Santos NM, Rezende MM, Terni A, et al. Perfil clínico e funcional dos pacientes com distrofia muscular de Duchenne assistidos na Associação Brasileira de Distrofia Muscular (ABDIM). Rev Neurocienc 2006;14:15-22.

9. Carvalho CRF. Caracterização da evolução respiratória em distrofia muscular de Duchenne: implicações da força muscular respiratória máxima. Tese, Livre-docência. São Paulo: Faculdade de Medicina, Universidade de São Paulo, 2004

10. Hartel JV, Granchelli JA, Hudecki MS, et al. Impact of prednisone on TGF beta 1 and collagen in diaphragm muscle from mdx mice. Muscle Nerve 2001;24:428-432.

11. Parreira SL, Resende MB, Della Corte Peduto M, et al. Quantification of muscle strength and motor ability in patients with Duchenne muscular dystrophy on steroid therapy. Arq Neuropsiquiatr 2007;65:245-250.

12. Daftary SA, Crisanti M, Kalra M, et al. Strength in patients with Duchenne muscular dystrophy effect of long-term steroids on cough efficiency and respiratory muscle. Pediatrics 2007;119:320-324.
13. Pradhan S, Ghosh D, Srivastava NK, et al. Prednisolone in Duchenne muscular dystrophy with imminent loss of ambulation. J Neurol 2006;253:13091316

14. Biggar WD, Harris VA, Eliasoph L, Alman B. Long-term benefits of deflazacort treatment for boys with Duchenne muscular dystrophy in their second decade. Neuromuscul Disord 2006;16:249-255.

15. Houde S, Filiatrault M, Fournier A. Deflazacort use in Duchenne muscular dystrophy: an 8-year follow-up. Pediatr Neurol 2008;38:200-206.

16. Toussaint M, Chatwin M, Soudon P. Mechanical ventilation in Duchenne patients with chronic respiratory insufficiency: clinical implications of 20 years published experience. Chron Respir Dis 2007;4:167-177.

17. Manzur AY, Kuntzer T, Pike M, Swan A. Glucocorticoid corticosteroids for Duchenne muscular dystrophy. Cochrane Database Syst Rev 2008: CD003725.

18. Bombardier C, Tugwell P. Methodologic considerations in functional assessment. J Rheumatol 1987;14 (Suppl 15):S6-S12.

19. Bowling A. Measuring disease. A review of disease-specific quality of life measurement scales. Edition 2. Philadelphia: Open University Press, 2001.

20. Teixeira-Salmela LF, Magalhães LC, Souza AC. Adaptação do perfil de saúde de Nottingham: um instrumento simples de avaliação da qualidade de vida. Cad Saúde Pública 2004;20:905-914.

21. Reid D, Renwick RM. Preliminary validation of a new instrument to measure life satisfation in adolescentes with neuromuscular disorders. Int J Rehabil Res 1994;17:184-188.

22. Rosner B. Fundamentals of Biostatistics. Ed 4. New York: Duxbury Press, 1994

23. Gonçalves M, Dylewski V, Xavier e Chaves AC, et al. Qualidade de Vida: análise comparativa entre crianças com distrofia muscular de Duchenne e seus cuidadores. Rev Neurociênc 2008;16:275-279.

24. Assumpção JR, Kuczynski E, Sprovieri MH, Aranha E. Escala de Avaliação de Qualidade de Vida (AUQEI) - Autoquestionnaire Qualité de Vie Enfant Imagé. Arq Neuropsiquiatr 2000;58:119-127.

25. Melo L-AE, Moreno-Valdes MT. Evaluation of the quality of life of children with Duchenne's progressive muscular dystrophy. Rev Neurol 2007;45: 81-87.

26. Ruta D, Garratt A, Abdalla M, Buckingham K, Russell I. The SF 36 health survey questionnaire. A valid measure of health status. BMJ 1993;307:448-449.

27. Ciconelli RM. Tradução para o português e validação do questionário genérico de avaliação de qualidade de vida do Medical Outcomes Study 36-Item Short Form Health Survey (SF-36). Tese de Doutorado. São Paulo: Escola Paulista de Medicina - UNIFESP, 1997.

28. Kohler M, Clarenbach CF, Bahler C, et al. Disability and survival in Duchenne muscular dystrophy. J Neurol Neurosurg Psychiatry 2009:80:320-325.

29. Bray P, Bundy AC, Ryan MM, North KN, Everett AJ. Health-related Quality of Life in boys with Duchenne muscular dystrophy: agreement between parents and their sons. J Child Neurol 2010 Mar 24. [Epub ahead of print] 